\title{
HYDROLOGICAL SIMULATION USING SWAT MODEL IN HEADWATER BASIN IN SOUTHEAST BRAZIL
}

\section{DONIZETE DOS R. PEREIRA ${ }^{1}$, MAURO A. MARTINEZ ${ }^{2}$, ANDRÉ Q. DE ALMEIDA ${ }^{3}$, FERNANDO F. PRUSKI ${ }^{4}$, DEMETRIUS D. DA SILVA ${ }^{5}$, JOÃO H. ZONTA ${ }^{6}$}

\begin{abstract}
Hydrological models are important tools that have been used in water resource planning and management. Thus, the aim of this work was to calibrate and validate in a daily time scale, the SWAT model (Soil and Water Assessment Tool) to the watershed of the Galo creek , located in Espírito Santo State. To conduct the study we used georeferenced maps of relief, soil type and use, in addition to historical daily time series of basin climate and flow. In modeling were used time series corresponding to the periods Jan 1, 1995 to Dec 31, 2000 and Jan 1, 2001 to Dec 20, 2003 for calibration and validation, respectively. Model performance evaluation was done using the Nash-Sutcliffe coefficient $\left(\mathrm{E}_{\mathrm{NS}}\right)$ and the percentage of bias $\left(\mathrm{P}_{\mathrm{BIAS}}\right)$. SWAT evaluation was also done in the simulation of the following hydrological variables: maximum and minimum annual daily flowsand minimum reference flows, $\mathrm{Q}_{90}$ and $\mathrm{Q}_{95}$, based on mean absolute error. $\mathrm{E}_{\mathrm{NS}}$ and $\mathrm{P}_{\mathrm{BIAS}}$ were, respectively, 0.65 and $7.2 \%$ and 0.70 and $14.1 \%$, for calibration and validation, indicating a satisfactory performance for the model. SWAT adequately simulated minimum annual daily flow and the reference flows, $Q_{90}$ and $Q_{95}$; it was not suitable in the simulation of maximum annual daily flows.
\end{abstract}

KEYWORDS: hydrological modeling, SWAT, calibration, validation

\section{SIMULAÇÃO HIDROLÓGICA USANDO O MODELO SWAT EM BACIA HIDROGRÁFICA DE CABECEIRA DA REGIÃO SUDESTE DO BRASIL}

RESUMO: Os modelos hidrológicos são ferramentas importantes que vêm sendo utilizadas no planejamento e na gestão dos recursos hídricos. Assim, objetivou-se com este trabalho calibrar e validar, numa escala de tempo diária, o modelo SWAT (Soil and Water Assesment Tool) para a bacia hidrográfica do Córrego do Galo, situada no Estado do Espírito Santo. Para a realização do estudo foram utilizados mapas georreferenciados de relevo, tipo e uso do solo, além de séries históricas diárias de clima e vazão da bacia. Na modelagem foram utilizadas séries temporais correspondentes aos períodos de $1^{\circ}$-1- 1995 a 31-12-2000 e $1^{\circ}-1-2001$ a 20-12-2013, para a calibração e validação, respectivamente. A avaliação do desempenho do modelo foi realizada usando os coeficientes de Nash-Sutcliffe $\left(\mathrm{E}_{\mathrm{NS}}\right)$ e percentual de viés ( $\left.\mathrm{P}_{\mathrm{BIAS}}\right)$. Também foram feitas avaliações do SWAT na simulação das seguintes variáveis hidrológicas: vazões máximas e mínimas diárias anuais; e vazões mínimas de referência $\mathrm{Q}_{90}$ e $\mathrm{Q}_{95}$, com base no erro médio absoluto. Os valores de $E_{N S}$ e $P_{\text {BIAS }}$ foram de 0,65 e $7.2 \%$ e 0,70 e $14.1 \%$, na calibração e na validação, respectivamente, indicando desempenho satisfatório do modelo. O SWAT simulou adequadamente as vazões mínimas diárias anuais e as de referência para outorga $Q_{90}$ e $Q_{95}$ e não foi adequado na simulação das vazões máximas diárias anuais.

PALAVRAS-CHAVE: modelagem hidrológica, SWAT, calibração, validação.

\footnotetext{
${ }^{1}$ Eng $^{0}$ Agrícola, Prof. Doutor, Instituto de Ciências Agrárias, UFV/Campus Florestal, Universidade Federal de Viçosa, Florestal MG, Fone: (31) 9889-4261, donizete.pereira@ufv.br

${ }^{2}$ Eng $^{\circ}$. Agrônomo, Prof. Titular, Departamento de Engenharia Agrícola, UFV, Viçosa-MG, (31) 3899 1910, mmauro@ufv.br

${ }^{3}$ Eng $^{\circ}$. Florestal, Prof. Doutor, Departamento de Engenharia Agrícola, UFS/São Cristóvão - SE,andre.almeida@ufs.br

${ }^{4}$ Eng $^{\circ}$ Agrícola, Prof. Titular, Doutor em Engenharia Agrícola, Universidade Federal de Viçosa, Viçosa -MG, Fone: (31) 38991912,ffpruski@ufv.br

${ }^{5}$ Eng . Agrônomo, Prof. Doutor, Departamento de Engenharia Agrícola, UFV, Viçosa-MG,(31)3899-1904, demetrius@ufv.br

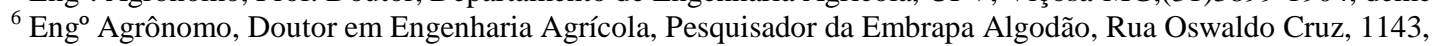

Centenário/Campina Grande - PB, Fone: (83) 3182-4411, joao-henrique.zonta@embrapa.br

Recebido pelo Conselho Editorial em: 12-6-2013
}

Aprovado pelo Conselho Editorial em: 1-3-2014 


\section{INTRODUCTION}

Hydrological studies in basins are important because they help to understand processes that control water movement and the likely impacts on water quantity and quality. In this sense, the quantitative understanding of hydrological parameters (rainfall and flow) and its spatial and temporal variability in regions or river basins should be seen as essential to an efficient planning and management of water resources (ARAI et al., 2012).

Impact assessments on water resources is one of the most relevant factors of hydrological models, which are fundamental tools for a basin planning and management (VIOLA et al., 2009). ANDRADE et al. (2013) report that hydrological models can be applied to evaluate management strategies for water resources and basin response to periodic climatic variations, project floods, real time floods. From an agricultural standpoint, hydrological simulation is an important tool for water resource management, characterizing grant flow for the irrigation projects (VIOLA et al., 2009). This characterization allows us to assess, in a preliminary way, water availability for irrigated agriculture, taking as reference $\mathrm{Q}_{90}$ and $\mathrm{Q}_{95}$ flows, for example.

Several hydrological models have been developed and applied in the simulation in several basins and varied purposes, such as SWAT (GREEN \& VAN GRIENSVEN, 2008), SMAP (SARAIVA et al., 2011), LASH (BESKOW et al., 2011), AnnAGNPS (YUAN et al., 2011), among others. Among the hydrological models, the conceptual distributed one should be emphasized, which simulate various processes that make up hydrological cycle based on empirical functions and input parameters in spatialized form, which is possible through model and Geographic Information System (GIS) integration.

With the advent of GIS, it has become easier to handle a large amount of data that distributed hydrological models demand, thus, enabling process simulations with greater physical foundation. However, hydrological models do not accurately represent water movement in a natural system that is why they should be calibrated with observed data (ANDRADE et al., 2013).

SWAT is a conceptual model, semi-distributed and continuous in time, and it was developed to predict effects of different uses, covers and soil managements on water and sediment production as well as water quality (DURÃES et al., 2011). For implementation and greater flexibility in simulation, the model has been highlighted in relation to others. SWAT has been calibrated and applied in hydrological simulation for several basins worldwide by several authors, such as GITHUI et al. (2009), in Western Kenya, in East Africa; HÖRMANN et al. (2009), in China, in Xiangxi River; and SEXTON et al. (2010), in Eastern shore of Chesapeake Bay in Maryland State - U.S.

Despite being widely used in hydrologic simulation in different river basins around the world, its use is still incipient in Brazil, being observed in a few studies, such as those of ANDRADE et al. (2013), DURÃES et al. (2011), BALTOKOSKI et al. (2010), LELIS \& CALIJURI (2010). Therefore, the model still needs to be applied on different conditions (climate, topography, soils, vegetation, etc.), as, for example, in headwater basins, especially those located in Southeastern coast of Brazil, a region which concentrates much of the country's population who has been suffering in recent years with consequences of extreme climatic effects.

The aim of this work was to calibrate and validate the SWAT model, in a daily scale, at conditions of Galo creek basin, ES, which is characterized as a headwater basin, and to evaluate their predictive ability in basin daily flow simulation.

\section{SUBJECT DESCRIPTION}

The study was conducted in Galo creek watershed, located in Domingos Martins town, Espirito Santo State, covering an area of $943 \mathrm{~km}^{2}$. The climate is Cwa, according to Köppen classification, with dry winter and rainy summer, where average temperature in the warmest month does not exceed $22{ }^{\circ} \mathrm{C}$ and in the coldest month is below $18{ }^{\circ} \mathrm{C}$. Average annual rainfall observed during the study period was $1250 \mathrm{~mm}$. 
For hydrological modeling of the the basin, the SWAT used informations (Figure 1) such as relief, soil type and its use, as well as historical daily time series of climate and river flow rate.

Relief information (Figure 1A) was obtained from Hydrographically Conditioned Digital Elevation Model (HCDEM), prepared based on planialtimetric maps from IBGE, in 1:50,000 scale, following method proposed by GUEDES \& SILVA (2012). Soil map was obtained from the Brazilian Institute of Geography and Statistics (IBGE), scale of 1:1,000,000 (Figure 1B). Soil basin is characterized as Red-Yellow Oxisols, which covers $92 \%$ of the area. Other expressive soil types are: Entisols (4.6\%), Inceptisols (2.1\%) and Dark and Red-Yellow Ultisols (1.1\%).

In the basin, Atlantic Forest vegetation and pasture correspond to approximately 53\% and $42 \%$ of the area, respectively (Figure 1C). Soil use mapping was get from Thematic Mapper (TM) sensor images aboard the Landsat 5, in 2005, with a spatial resolution of $30 \mathrm{~m}$. Initially, images were preprocessed and georeferenced, obtaining a Mean Squared Error (MSE) of 8.5 meters. Supervised classifier of Maximum Likelihood (Maxver) was used to map soil use. The blue, green, red and near infrared spectral bands were considered in supervised classification.

Input climatic data for the model were extracted from two points of Climatic Research Unit grid (NEW et al., 2000). Four rainfall stations and a gaging station on basin exutory area were used (Figure 1A), obtained from HIDROWEB/ANA database. Used data were rainfall (mm), maximum and minimum air temperature $\left({ }^{\circ} \mathrm{C}\right)$, solar radiation $\left(\mathrm{Mj} \mathrm{m}^{-2} \mathrm{~s}^{-2}\right)$, wind speed $\left(\mathrm{m} \mathrm{s}^{-1}\right)$ and air relative humidity (\%), all in the daily time scale. ANA (National Water Agency), by converting the height values of the water depth, estimate output flow rate of the basin $\left(\mathrm{m}^{3} \mathrm{~s}^{-1}\right)$ daily.

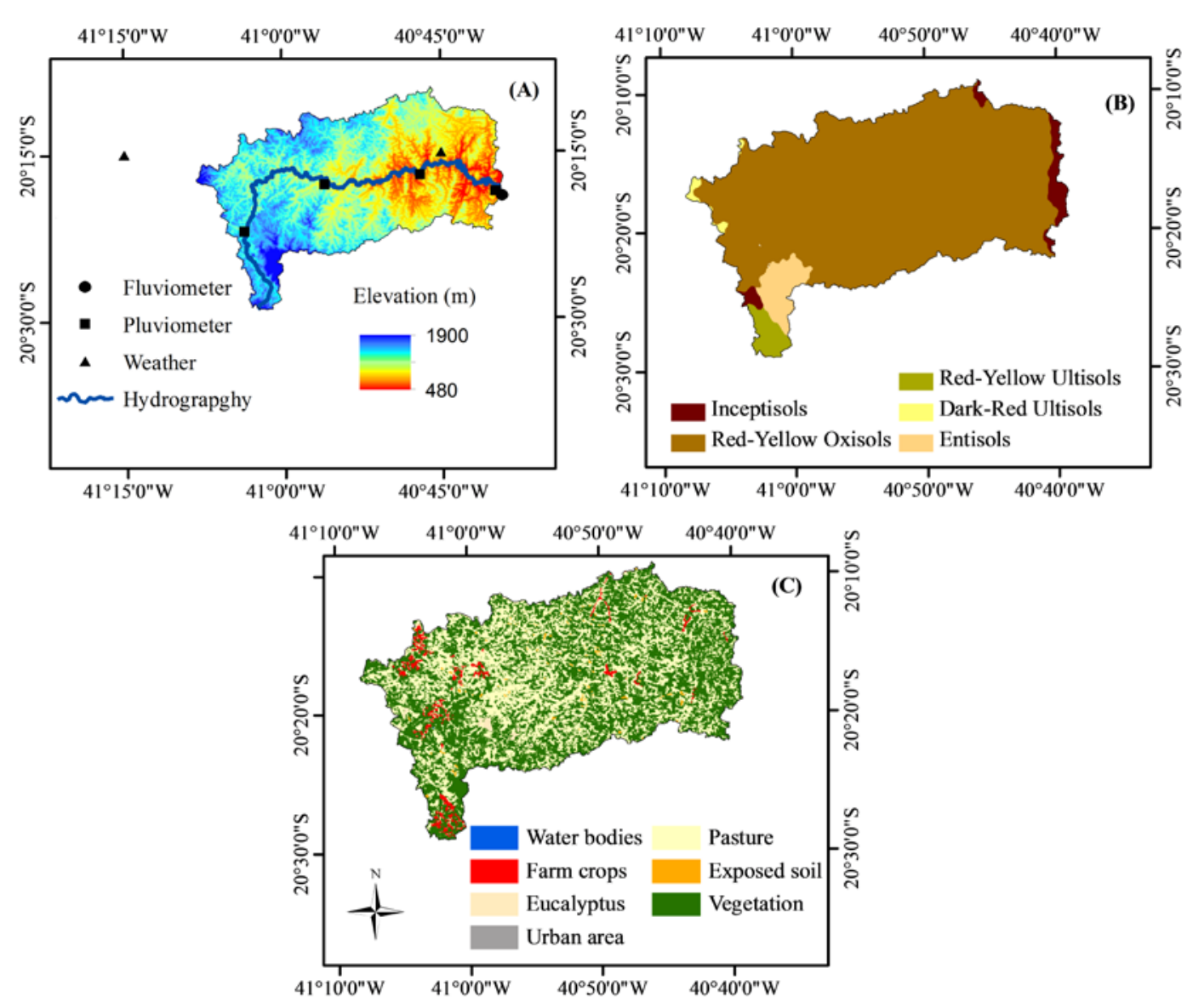

FIGURE 1. Hydrographically Conditioned Digital Elevation Model (HCDEM) (A), soil type map (B) and soil use and occupation (C) of Galo creek basin for application in SWAT.

Hydrological simulation was performed with the 2005 version of SWAT model through an interface between the model and ArcGIS software that is called ARCSWAT. Through this, the 
basin was divided into sub-basins based on HCDEM and, then, each sub-basin was subdivided into Hydrological Response Units (HRUs) which are homogeneous areas in respect to vegetation and soil type.

Each HRU was associated with a climate database, soil hydro-physical characteristics, groundwater and vegetation. Hydro-physical soil characteristics were obtained from RADAMBRASIL (1983) regarding the soil profiles of 18, 28, 29, 41 and 64. As input values for the hydraulic conductivity of saturated soil were adopted those obtained in field by MORAES et al. (2003) and ZONTA et al. (2010). Groundwater and vegetation data were obtained from model database, with changes in some parameters of vegetation, according to Table 1.

TABLE 1. Vegetation parameters modified from SWAT database for hydrological simulation in the Galo creek basin.

\begin{tabular}{|c|c|c|c|c|c|}
\hline Vegetation type & $\operatorname{BLAI}\left(\mathrm{m}^{2} \mathrm{~m}^{-2}\right)$ & $\begin{array}{c}\text { GSI } \\
\left(\mathrm{m} \mathrm{s}^{-1}\right)\end{array}$ & RDMX (m) & $\begin{array}{l}\mathrm{OV}_{-} \mathrm{N} \\
\left(\mathrm{s} \mathrm{m}^{-1 / 3}\right)\end{array}$ & Source \\
\hline Original vegetation & $7.5^{(1)}$ & $0.017^{(3)}$ & $5.0^{(1)}$ & $0.3^{(4)}$ & ${ }^{(1)}$ ALMEIDA \& SOARES (2003) \\
\hline Eucalyptus & $4.0^{(1)}$ & $0.01^{(1)}$ & $2.5^{(1)}$ & $0.12^{(4)}$ & ${ }^{(2)}$ VIOLA et al. (2009) \\
\hline Agriculture & $7.0^{(2)}$ & $0.014^{(5)}$ & $1.5^{(5)}$ & $0.19^{(4)}$ & (3) SÁ et al. (1996) \\
\hline Pasture & $3.0^{(2)}$ & $0.013^{(3)}$ & $0.6^{(2)}$ & $0.15^{(4)}$ & $\begin{array}{l}\text { (4) NEITSCH et al. (2011) } \\
\text { (5) Valor médio }\end{array}$ \\
\hline
\end{tabular}

BLAI - maximum leaf area index; GSI - maximum stomatal conductance; RDMX - maximum root depth and OV_N -Manning coefficient for soil surface.

With the input parameters, water balance component modeling in daily time scale was performed according to method suggested by Neitsch et al. (2009), as follows:

$$
\mathrm{SW}_{\mathrm{t}}=\mathrm{SW}_{0}+\sum_{\mathrm{i}=1}^{\mathrm{n}}\left(\mathrm{P}_{\mathrm{i}}-\mathrm{Q}_{\text {sup }_{\mathrm{i}}}-\mathrm{Q}_{\text {lati }_{\mathrm{i}}}-\mathrm{ET}_{\mathrm{i}}-\mathrm{Q}_{\text {subi }_{\mathrm{i}}}\right)
$$

where $\mathrm{SW}_{\mathrm{t}}$ - final water content of the soil, mm; $\mathrm{SW}_{0}$ - initial soil water content, $\mathrm{mm}$; $\mathrm{P}_{\mathrm{i}}$ pluvial precipitation, mm; $\mathrm{Q}_{\text {supi }}$ - surface runoff, mm; $\mathrm{Q}_{\text {lati }}$ - lateral flow, $\mathrm{mm}$; $\mathrm{E}_{\mathrm{Ti}}$ evapotranspiration, $\mathrm{mm}$; and $\mathrm{Q}_{\text {subi }}$ - groundwater flow, mm.

The model estimates runoff through curve number method (SCS - CN) or Green Ampt model (GREEN \& AMPT, 1911; ARNOLD et al., 2011), which was selected for the curve number simulation method. Regarding lateral flow component, the method for its storage kinematic estimate is used. To estimate real evapotranspiration (ET), the model calculates separately plant transpiration and water evaporation from soil. Transpiration is estimated by correcting potential evapotranspiration to conditions of vapor pressure deficits and then to water content in soil. Potential evapotranspiration was estimated by the Penman-Monteith method (JENSEN et al., 1990; ARNOLD et al., 2011).

Groundwater flow is estimated by separating the contribution of shallow and deep aquifers, where shallow aquifer contribution is considered in water balance and the deep as system loss (ARNOLD et al., 2011).

Two data series of daily flow, corresponding to $1 / 1 / 1995$ to $12 / 31 / 2000$ and $1 / 1 / 2001$ to 12/20/2003 were respectively used for model calibration and validation. The years 1995 and 1996 were used as model warm-up period, since initial conditions were unknown. Warm-up period is aimed at stabilizing initial conditions of soil water (VIOLA et al., 2009; CIBIN et al., 2010), which was observed from second year of simulation (Figure 2).

Due to calibrated SWAT model has several parameters, those with higher calibration sensitivity, in response to changes in their values were selected, which were determined by specific 
procedure of sensitivity analysis of model parameters, namely: ALPHA_BF; $\mathrm{CH}_{-} \mathrm{N}_{2}$; $\mathrm{CN}_{2}$; ESCO; SOL_AWC; SOL_K and SURLAG.

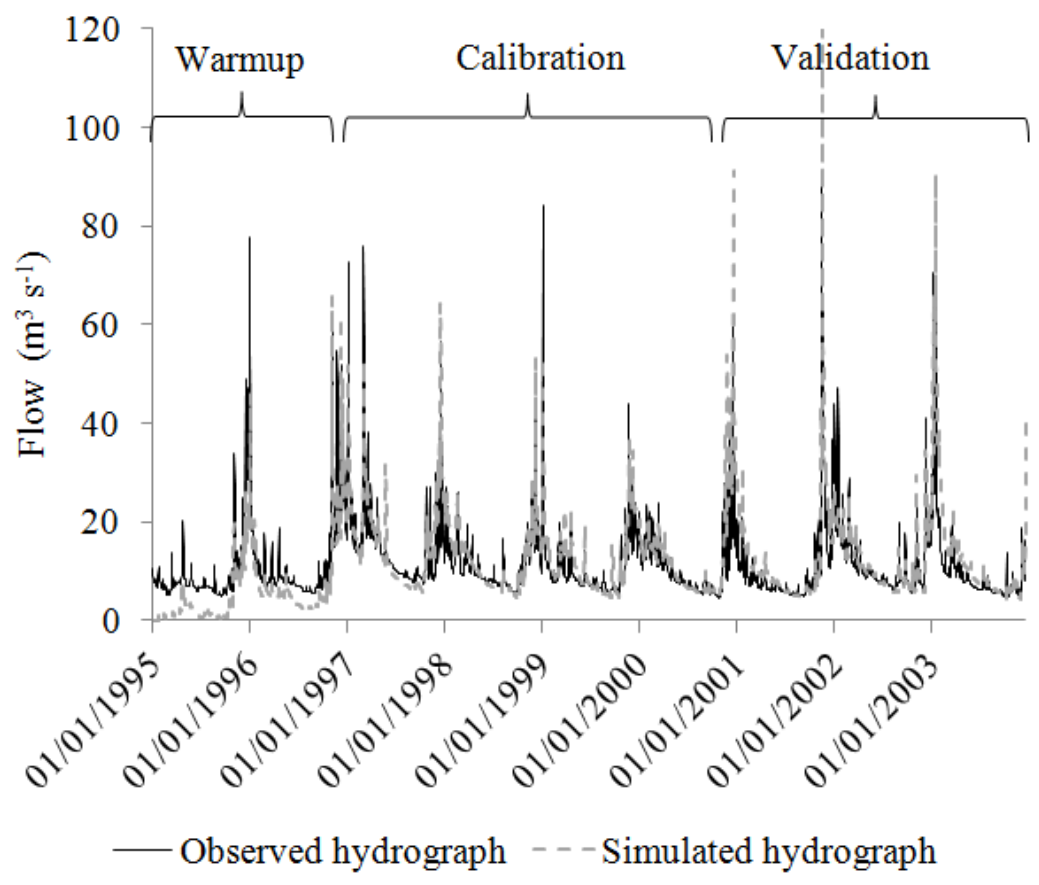

FIGURE 2. Periods used for warm-up calibration and validation of SWAT model.

Calibration was performed by trial and error method, seeking to maximize objective function coefficient of Nash-Sutcliffe efficiency $\left(\mathrm{E}_{\mathrm{NS}}\right)$, minimizing percentage of bias ( $\left.\mathrm{P}_{\mathrm{BIAS}}\right)$, according to Eqs 2 and 3, respectively, in addition to good adjustment of simulated hydrograph compared to the observed one. Process was interrupted when, statistical coefficients were no longer able to be improved, and when a good fit of hydrograph was seen (simulated and observed).

$$
\begin{aligned}
& \mathrm{E}_{\mathrm{NS}}=1-\frac{\sum_{\mathrm{i}=1}^{\mathrm{n}}\left(\mathrm{O}_{\mathrm{i}}-\mathrm{P}_{\mathrm{i}}\right)^{2}}{\sum_{\mathrm{i}=1}^{\mathrm{n}}\left(\mathrm{O}_{\mathrm{i}}-\overline{\mathrm{O}}\right)^{2}}(2) \\
& \mathrm{P}_{\text {BIAS }}=\left(\frac{\sum_{\mathrm{i}=1}^{\mathrm{n}} \mathrm{P}_{\mathrm{i}}-\sum_{\mathrm{i}=1}^{\mathrm{n}} \mathrm{O}_{\mathrm{i}}}{\sum_{\mathrm{i}=1}^{\mathrm{n}} \mathrm{O}_{\mathrm{i}}}\right) \cdot 100
\end{aligned}
$$

where,

$E_{N S}$ - coefficient of Nash-Sutcliffe efficiency

$\mathrm{P}_{\text {BIAS }}$ - percentage of bias

$\mathrm{O}_{\mathrm{i}}$ and $\mathrm{P}_{\mathrm{i}}$ - observed and estimated values, respectively

$\overline{\mathrm{O}}$ - observed values average

$\mathrm{n}$ - number of observations during the simulated period

To evaluate model accuracy based on $E_{\text {NS }}$ coefficient, van LIEW et al. (2007) classification was adopted and used by several authors (VIOLA et al., 2009; DURÃES et al., 2011, ANDRADE et al., 2013). According to this classification, $E_{N S}$ value $=1$ means perfect fit data simulated by the model; $\mathrm{E}_{\mathrm{NS}}>0.75$ (model is suitable and good); $0.36<\mathrm{E}_{\mathrm{NS}}<0.75$ model is satisfactory and $<0.36$ model is not satisfactory. Nash-Sutcliffe coefficient efficiency informs model effectiveness in predicting flood flows. 
Classification by Van Liew et al. (2007) was also adopted to evaluate model accuracy based

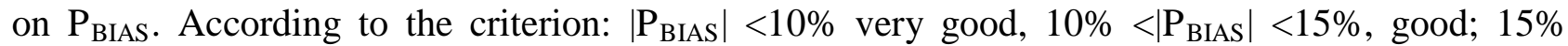
$<\left|\mathrm{P}_{\mathrm{BIAS}}\right|<25 \%$, satisfying and $\left|\mathrm{P}_{\mathrm{BIAS}}\right| \geq 25 \%$, unsatisfactory. Bias percentage it means to average deviations simulated compared to observed flow data .

Calibration process was terminated when $\mathrm{E}_{\mathrm{NS}}$ and $\left|\mathrm{P}_{\mathrm{BIAS}}\right|$ values were greater than 0.6 and less than $15 \%$, and when simulated hydrograph had good fit to the observed.

Besides described statistics, mean absolute error was used to evaluate the following hydrologic variables simulated by SWAT, during periods of calibration and validation: maximum and minimum annual daily flows; and references minimum flows $\mathrm{Q}_{90}$ and $\mathrm{Q}_{95}$ to grant use of water extracted from the remaining curve, according to Eq. 4.

$$
\overline{\mathrm{e}}=\frac{\sum_{\mathrm{i}=1}^{\mathrm{n}} \frac{\left|\mathrm{O}_{\mathrm{i}}-\mathrm{P}_{\mathrm{i}}\right|}{\mathrm{O}_{\mathrm{i}}}}{\mathrm{n}}
$$

\section{RESULTS AND DISCUSSION}

Table 2 shows the values of the SWAT parameters calibrated for the Galo creek basin and their respective ranges of allowed variation.

TABLE 2. Values of SWAT parameters calibrated for Galo creek basin with their respective allowed variation ranges and searched sources.

\begin{tabular}{cccc}
\hline Parameter & Variation range & Reference & Calibrated value \\
\hline ALPHA_BF & $(0-1)$ & NEITSCH et al. (2011) & 0.004 \\
CH_N2 & $(0.01-0.059)$ & LYRA et al. (2010) & 0.011 \\
CN2 & $(-5-+5)$ & - & -3.0 \\
ESCO & $(0.01-1)$ & NEITSCH et al. (2011) & 0.9 \\
SOL_AWC & $(-0.1-+0.1)$ & - & +0.08 \\
SOL_K & $(-90-+90 \%)$ & MORAES et al. (2003) & $-90 \%$ \\
SURLAG & $(0-4)$ & GREEN \& VAN GRIENSVEN (2008) & 0.15 \\
\hline
\end{tabular}

ALPHA_BF - aquifer recession constant; $\mathrm{CH}_{-} \mathrm{N}_{2}$-Manning coefficient of main channel; $\mathrm{CN}_{2}$ - curve number; ESCO - soil evaporation compensation factor; SOL_AWC - soil available water capacity; SOL_K - hydraulic conductivity of saturated soil; SURLAG - runoff delay coefficient.

Calibrated values for ALPHA_BF (0.004), CH_N 2 (0.011), ESCO (0.9) and SURLAG (0.15) parameters should replace input values used by SWAT model. Regarding $\mathrm{CN}_{2}(-3.0)$ and AWC $(+0.08)$ parameters, these must be subtracted and added, respectively, to the input value used by the model, and regarding SOL_K parameter (-90\%), it means that model input values need to be multiplied by 0.1 , i.e., a reduction of $90 \%$. Regarding adopted intervals, these were obtained from literature, as reference (Table 2). Regarding $\mathrm{CN}_{2}$ parameter, its variation range was defined within 5 to +5 (added and subtracted from the initial value) due to soil groups presented $\mathrm{CN}_{2}$ input values higher than 90 and lower than 35, so that an interval of greater variation become physically meaningless.

Figure 3 presents the simulated hydrographs with SWAT for the calibration period (A) and validation (B), in addition to their daily hydrographs and hyetographs observed in Galo creek basin.

For the periods of calibration and validation $E_{N S}$ values of 0.65 and 0.70 were found, respectively, which provides the basis for the model to be satisfactory according to classification suggested by van LIEW et al. (2007).

ANDRADE et al. (2013) calibrated and validated SWAT in predicting a representative basin flow with Oxisols in Upper Rio Grande, Minas Gerais regions and obtained values of $E_{N S}$ of 0.66 and 0.87 in calibration and validation. DURÃES et al. (2011) applied SWAT in Paraopeba River 
basin, $\mathrm{MG}$, and obtained values of $\mathrm{E}_{\mathrm{NS}}$ equal to 0.79 in both calibration and validation. In all these simulations, SWAT model was considered accurate and qualified for hydrological simulations in these regions. In general, it is observed that SWAT model calibrated to Galo creek basin presented statistics close to those observed in literature, and in some cases even higher, qualifying the model for hydrologic simulation in that river basin.

Analyzing the performance of the model based on $\mathrm{P}_{\text {BIAS }}$ criterion, which estimates bias percentage of simulated streamflow compared to observed ones, small deviations are verified demonstrating that flow overestimation occurred in the amount of 7.2 and $14.1 \%$, for calibration and validation periods, respectively. According to the classification suggested by van LIEW et al. (2007) model fits as very good in calibration period and good in validation.
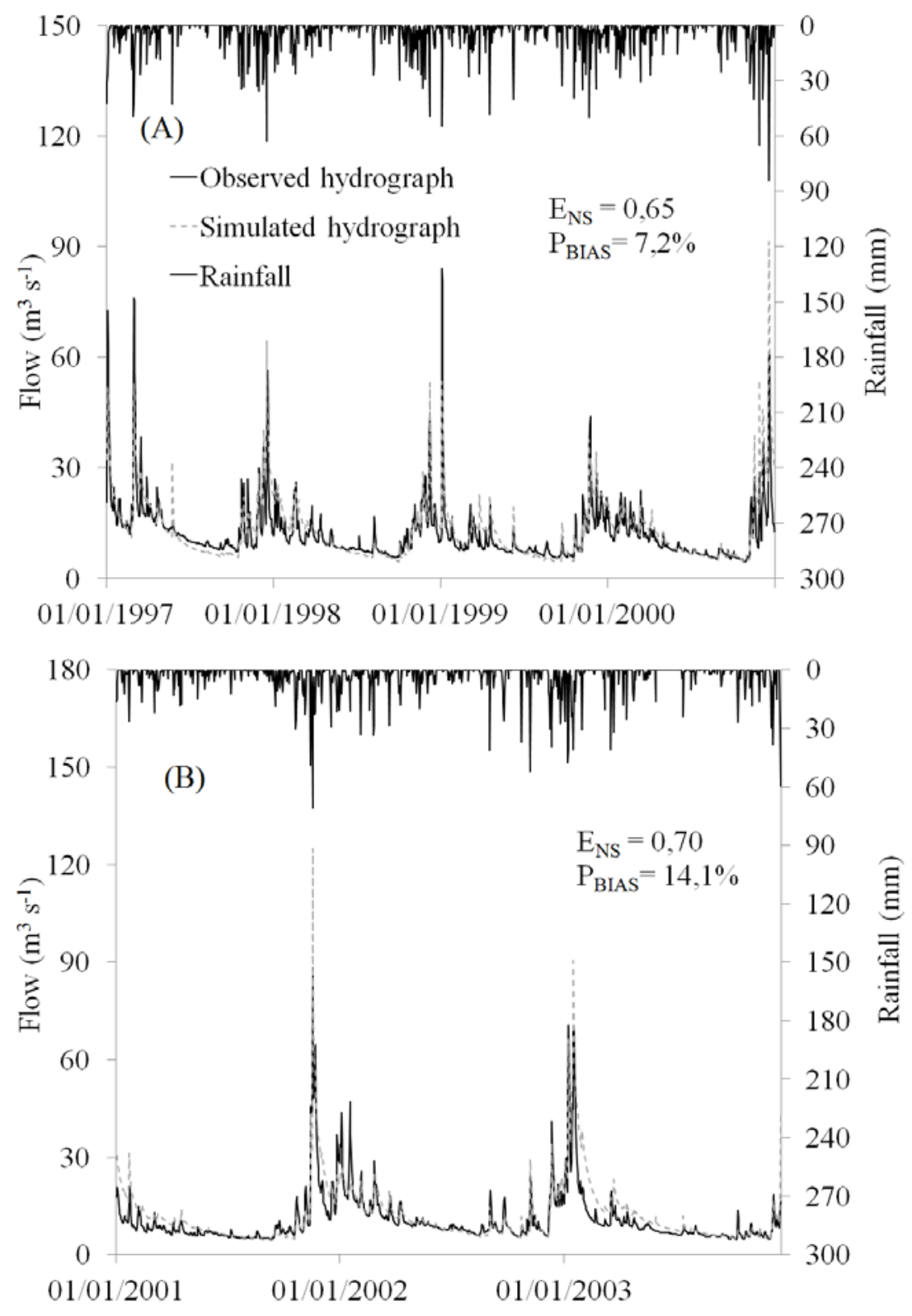

FIGURE 3. Observed and simulated hydrographs for Galo creek basin during calibration (A) and validation (B) periods, in addition to their daily hyetographs.

Analyzing hydrographs visually, good estimates of minimum flows are observed, both during calibration and validation periods. As for peak flows, the model did not adequately simulate those more extreme events, both in calibration and validation. Flow peaks are naturally difficult to model and related to spatial and temporal rainfall representation associated with low concentration time of 
runoff and river basins. This difficulty was also observed by other authors, such as HÖRMANN et al. (2009), SETEGN et al. (2010), ANDRADE et al. (2013).

In order to evaluate the SWAT model for a more specific application in planning and management of water resources in Galo creek basin, retention curves observed and simulated (Figure 4) and the values of maximum and minimum annual daily flow are presented (Table 3).

Analyzing the curves visually, there is a good adhesion of the simulated values compared to those observed, especially for the flow to remain above $50 \%$ in time. The reference values of $\mathrm{Q}_{90}$ and $\mathrm{Q}_{95}$, extracted from this curve, are widely used in planning and management of water resources in basins and represent equaled or exceeded flow in 90 and $95 \%$ of the time, respectively. The values simulated by SWAT were 5.1 and $4.8 \mathrm{~m}^{3} \mathrm{~s}^{-1}$, and the observed values of 5.4 and $5.0 \mathrm{~m}^{3} \mathrm{~s}^{-1}$, which corresponds to absolute errors of only 5.6 and $4 \%$, respectively, compared to the observed ones. These small estimation errors attest to the quality of SWAT model for water resources management in Galo creek basin.

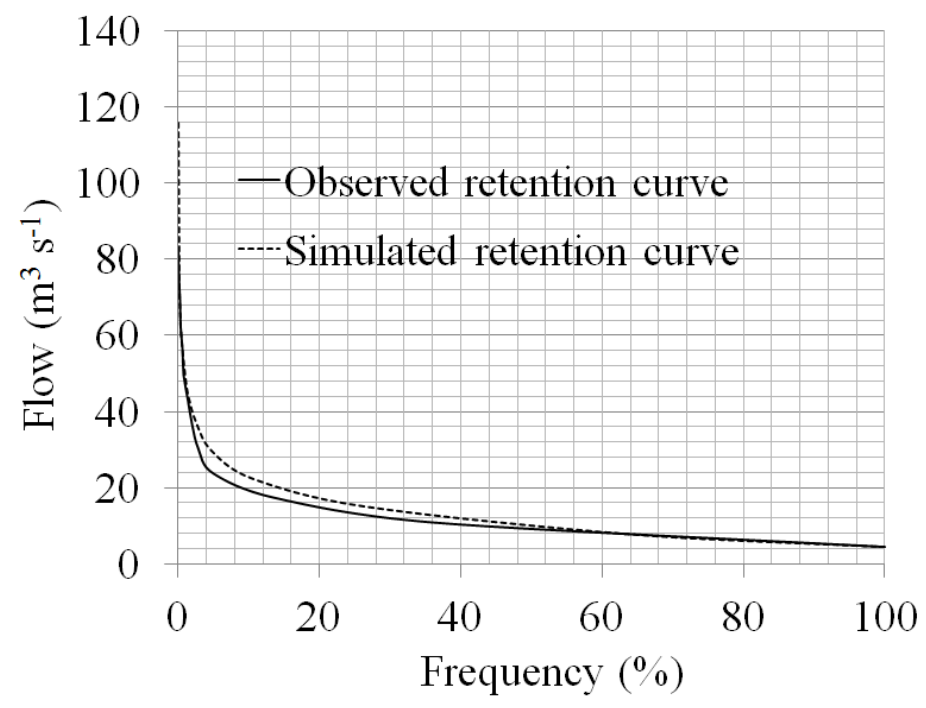

FIGURE 4. Retention curves observed and simulated with SWAT for Galo creek basin.

TABLE 3. Comparison of maximum and minimum annual daily flow simulated with SWAT model and observed for Galo creek basin.

\begin{tabular}{ccccccc}
\hline \multirow{2}{*}{ Year } & \multicolumn{2}{c}{$\mathrm{Q}_{\text {maximum }}\left(\mathrm{m}^{3} \mathrm{~s}^{-1}\right)$} & \multirow{2}{*}{ Erro $(\%)$} & \multicolumn{2}{c}{$\mathrm{Q}_{\text {minimum }}\left(\mathrm{m}^{3} \mathrm{~s}^{-1}\right)$} & Error (\%) \\
\cline { 2 - 3 } \cline { 5 - 6 } & $\mathrm{V}_{\text {obs }}$ & $\mathrm{V}_{\text {pred }}$ & & $\mathrm{V}_{\text {obs }}$ & $\mathrm{V}_{\text {pred }}$ & \\
\hline 1997 & 76.05 & 64.40 & 15.3 & 7.27 & 5.61 & 22.8 \\
1998 & 44.81 & 53.10 & 18.5 & 5.59 & 4.59 & 17.9 \\
1999 & 84.08 & 53.40 & 36.5 & 5.59 & 4.43 & 20.8 \\
2000 & 61.47 & 91.30 & 48.5 & 4.45 & 4.48 & 0.7 \\
2001 & 88.22 & 125.00 & 41.7 & 4.62 & 4.41 & 4.5 \\
2002 & 47.20 & 34.40 & 27.1 & 5.43 & 5.42 & 0.2 \\
2003 & 70.51 & 90.40 & 28.2 & 4.47 & 4.34 & 2.9 \\
\hline Average & & 30.8 & & & 10.0 \\
\hline
\end{tabular}

It is observed in Table 3 that absolute errors in simulation of annual maximum daily flows for SWAT model ranged from 15.3 to $48.5 \%$, with an average error of $30.8 \%$, compared to the observed values. As for simulation of minimum values of annual daily flow, errors ranged from 0.2 to $22.8 \%$, with a mean absolute error of $10 \%$, in validation period (2001-2003) small errors were observed. 
Model errors in simulation of minimum flows and reference extracted from curve are within a range considered acceptable in hydrology. However, errors in simulation of maximum extreme values, which came close to 50\%, indicate non-suitability of the model for estimation of this variable, precluding its use in dimensioning flood control infrastructure.

Deviations in simulation of flow peaks are explained by the fact that Galo creek basin is in headwater area, with altitudes ranging 1900 to 480 meters, this contributes to flood flow occurrence, which are hard to be simulated by the model, due to the lower concentration time of the basin $(\sim 15 \mathrm{~h})$. This basin peculiarity associated with occurrence of intense rainfall, as in November 2001, when it rained $190 \mathrm{~mm}$ due to four very rainy days, contributed to flood flow of $88.2 \mathrm{~m}^{3} \mathrm{~s}^{-1}$ at the basin outlet, hindering the modeling.

Based on acceptable errors in annual minimum daily flow simulation and small errors in reference flows, adopted for water use grant in Brazil, which may contribute to basin water resources management and hence for irrigated agriculture, a satisfactory performance of SWAT model is confirmed, qualifying it for hydrologic simulation in Galo creek basin.

\section{CONCLUSIONS}

The calibration and validation of the SWAT model for Galo creek basin, characterized as a headwater basin, was very good. The model showed good predictive ability for annual minimum daily flow rates and for reference flow rates , adopted for purposes of granting water use in Brazil. In contrary, the model showed considerable estimation errors in annual maximum daily flow simulations, not qualifying it for this type of simulation.

\section{REFERENCES}

ALMEIDA, A.C.; SOARES, J.V. Comparação entre uso de água em plantações deEucalyptus Grandis e Floresta Ombrófila Densa (Mata Atlântica) na costa leste do Brasil. Revista Árvore, Viçosa, MG, v.27, n.2, p.159-170, mar/abr. 2003.

ANDRADE, M.A.; MELLO, C.R.; BESKOW, S. Simulação hidrológica em uma bacia hidrográfica representativa dos Latossolos na região Alto Rio Grande, MG. Revista Engenharia Agrícola e Ambiental, Campina Grande, v.17, n.1, p.69-76, jan. 2013.

ARAI, F.K.; PEREIRA, S.B.; GONÇALVES, G.G.G. Characterization of water availability in a hydrographic basin. Engenharia Agrícola, Jaboticabal, v.32, n.3, p.591-601, maio/jun. 2012.

ARNOLD, J.G.; KINIRY, J.R.; SRINIVASAN, R.; WILLIAMS, J.R.; HANEY, E.B.; NEITSCH, S.L. Soil and water assessment tool input/output file documentation version 2009. Disponível em: <http://swat.tamu.edu/media/19754/swat-io-2009.pdf $>$. Acesso em 11 jan. de 2013.

BALTOKOSKI, V.; TAVARES, M.H.F.; MACHADO, R.E.; OLIVEIRA, M.P. Calibração de modelo para simulação de vazão e de fósforo total nas sub-bacias do rio Conrado e Pinheiro - Pato Branco (PR). Revista Brasileira de Ciência do Solo, Viçosa, MG, v.34, n.1, p.253-261, jan./fev. 2010.

BESKOW, S.; MELLO, C. R.; NORTON, L. D.; SILVA, A. M. Performance of a distributed semiconceptual hydrological model under tropical watershed conditions. Catena, Amsterdam, v.86, n.3, p.160-171, set. 2011.

CIBIN, R.; SUDHEER, K.P.; CHAUBEY, I. Sensitivity and identifiability of stream flow generation parameters of the SWAT model. Hydrological Processes, Chichester, v.24, n.9, p.11331148, jan. 2010.

DURÃES, M.F.; MELLO, C.R.; NAGHETTINI, M. Applicability of the SWAT model for hydrologic simulation in Paraopeba River Basin, MG. Cerne, Lavras, v.17, n.4, p.481-488, out/dez. 2011. 
GITHUI, F.; GITAU, W.; MUTUA, F; BAUWENS, W. Climate change impact on SWAT simulated streamflow in western Kenya. International Journal of Climatology, Chichester, v.29, n.12, p.1823-1834, out. 2009.

GREEN, W.; AMPT, G. Studies on soil physics part I: the flow of air and water through soils. Journal of Agricultural Science, Cambridge, n.4, p.1-24, 1911.

GREEN, C.H.; VAN GRIENSVEN, A. Autocalibration in hydrologic modeling: Using SWAT2005 in small-scale watersheds. Environmental Modelling \& Software, Oxford, v.23, n.4, p. 422 - 434, abril. 2008.

GUEDES, H.A.S.; SILVA, D.D. comparison between hydrographically conditioned digital elevation models in the morphometric charaterization of watersheds. Engenharia Agrícola, Jaboticabal, v.32, n.5, p.932-943, set./out. 2012.

HÖRMANN, G.; KÖPLIN, N.; CAI, Q.; FOHRER, N. Using a simple model as a tool to parameterise the SWAT model of the Xiangxi river in China. Quaternary International, Heshigton, v.208, n.1/2, p.116-120, out. 2009.

INSTITUTO BRASILEIRO DE GEOGRAFIA E ESTATÍSTICA. Diretoria de Geociências. Departamento de Cartografia. IBGE. Folha SF-24-V-A-III-4. Disponível em: <ftp://geoftp.ibge.gov.br/>. Acesso em: 31 jan. 2014.

JENSEN, M.E.; BURMAN, R.D.; ALLEN, R.G. Evapotranspiration and irrigation water requirements. ASCE Manuals and Reports on Engineering Practice. ASCE, Nova York, n.70, 1990, 332p.

LELIS, T.A.; CALIJURI, M.L. Modelagem hidrossedimentológica de bacia hidrográfica na região sudeste do Brasil, utilizando o SWAT. Revista Ambiente \& Água, Taubaté, v.5, n.2, p.158-174, 2010.

LYRA, G. B.; CECÍLIO, R.A.; ZANETTI, S.S. Coeficiente de rugosidade de Manning para o rio Paracatu. Revista Brasileira de Engenharia Agrícola e Ambiental, Campina Grande, v.14, n.4, p.343-350, abr. 2010.

MORAES, J. M.; SCHULER, A. E.; GUANDIQUE, M. E. G.; MILDE, L. C.; GROPPO, J. D.; MARTINELLI, L. A.; VICTORIA, R. L. Propriedades físicas dos solos na parametrização de um modelo hidrológico. Revista Brasileira de Recursos Hídricos, Porto Alegre, v.8, n.1, p.61-70, jan/mar. 2003.

NEITSCH, S.L.; ARNOLD, J.G.; KINIRY, J.R.; WILLIAMS, J.R. Soil and water assessment tool Theoretical documentation version 2009. 618p. Disponível em:

< $\underline{\text { http://twri.tamu.edu/reports/2011/tr406.pdf> }}$. Acesso em: 11 jun. 2013, set. 2011.

NEW, M.; HULME, M.; JONES, P.D. Representing twentieth century space-time climate variability. Part 2: development of 1901-96 monthly grids of terrestrial surface climate. Journal of Climate, Boston, v.13, n.3, p.2217-2238, jul. 2000.

RADAMBRASIL. Radar na Amazônia. Levantamento de recursos naturais: Folhas SF-23/24 - Rio de Janeiro/Vitória: geologia, geomorfologia, pedologia, vegetação e uso potencial da terra. Rio de Janeiro. Ministério das Minas e Energia, 1983, v.32, 780p.

SÁ, T.D.A.; COSTA, J.P.R.; ROBERTS, J.M. Forest and pasture conductances in southern Pará, Amazonia. In: GASH, J.H.C.; NOBRE, C.A.; ROBERTS, J.M.; VICTORIA, R.L. Amazonian Deforestation and Climate. New Jersey: John Wiley \& Sons, 1996. p. 241 - 264.

SARAIVA, I.; FERNANDES, W.; NAGHETTINI, M. Simulação hidrológica mensal em bacias sem monitoramento fluviométrico. Revista Brasileira de Recursos Hídricos, Porto Alegre, v.16, n.1, p.115-125, jan/mar, 2011. 
SETEGN, S. G.; SRINIVASAN, R.; MELESSE, A. M.; DARGAHI, B. SWAT model application and prediction uncertainty analysis in the Lake Tana Basin, Ethiopia. Hydrological Processes, Chichester, v. 24, n.3, p.357-367, jan. 2010.

SEXTON, A.M.; SADEGHI, A.M.; ZHANG X.; SRINIVASAN, R.; SHIRMOHAMMADI, A. Using NEXRAD and rain-gauge precipitation data for hydrologic calibration of SWAT in northeastern watershed. Transactions of the ASABE, Saint Joseph, v.53, n.5, p.1501-1510, set./out. 2010.

van LIEW, M.W.; VEITH, T.L.; BOSCH, D.D.; ARNOLD, J.G. Suitability of SWAT for the Conservation effects assessment project: A comparison on USDA - ARS watersheds. Journal of Hydrologic Engineering, Reston, v.12, n.2, p.173 - 189, mar./abr. 2007.

VIOLA, M.R.; MELLO, C.R.; ACERBI JR, F.W.; SILVA, A.M. Modelagem hidrológica na bacia hidrográfica do Rio Aiuruoca, MG. Revista Engenharia Agrícola e Ambiental, Campina Grande, v.13, n.5, p.581-590, set/out. 2009.

YUAN, Y.; BINGER, R.L.; LOCKE, M.A.; THEURER, F.D.; STAFFORD, J. Assessment of subsurface drainage management practices to reduces nitrogen loadings using AnnAGNPS. Applied Engineering in Agriculture, Saint Joseph, v.27, n.3, p.335-344, 2011.

ZONTA, J.H.; MARTINEZ, M.A.; PRUSKI, F.F.; SILVA, D.D.; MONTEBELLER, C.A. Adequação dos parâmetros do modelo de Green-Ampt-Mein-Larson em condições de campo. Revista Engenharia Agrícola e Ambiental, Campina Grande, v.14, n.10, p.1021-1029, out. 2010. 